\author{
Хрип'юк В. І. \\ аспірант \\ Кафредра економіки і права \\ Національний університет харчових технологій \\ вул. Володимирська, 68, м. Київ, Україна, 01601 \\ E-mail: viktorija2511@ukr.net
}

\title{
ДЕРЖАВНЕ РЕГУЛЮВАННЯ ІННОВАЦІЙНО-ОРІЄНТОВАНОГО РОЗВИТКУ ХАРЧОВОЇ ПРОМИСЛОВОСТІ УКРАЇНИ
}

У статті розглянуто теоретичні засади композиції державного регуляторного механізму активізації інноваційних процесів у визначених інституційних ланках харчової промисловості України. Визначені «сильні» та «слабкі» регуляторні важелі (через критеріальний базис світовизнаного Глобального інноваційного індексу), що формують інноваційний клімат у агропродовольчому секторі країни. Обґрунтовано перспективні напрями удосконалення державного регулювання інноваційного розвитку харчової промисловості України та з використанням авторського підходу визначені відповідні галузеві пріоритети.

Ключові слова: державне регулювання, інноваційна активність, глобальний інноваційний індекс, харчова промисловість, продовольча безпека.

This work is licensed under a Creative Commons Attribution 4.0 International License http://creativecommons.org/licenses/by/4.0/

Постановка проблеми та її зв'язок з важливими науковими та практичними завданнями. В результаті аграрних реформ, в рамках переходу української економіки на функціонування в ринкових умовах господарювання, багато підприємств харчової промисловості виявились неефективними і завершили свою діяльність, що призвело до значних соціальних потрясінь, фінансово-економічних проблем, інституційних «пасток», дефіциту вітчизняної сільськогосподарської сировини, який спричинив масові їі закупівлі за кордоном, при чому не завжди задовільної якості. Все це в підсумку призвело до скорочення кількісних значень інституційних одиниць в галузевій

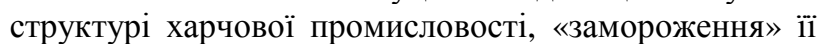
ортодоксальної планово-орієнтованої галузевої структури, дестимуляції інноваційної діяльності, відповідних інвестиційних процесів, зниження до критичного рівня продовольчої безпеки, формування контурів прихованого голоду, хоча Україна має відповідний ресурсний потенціал (природно-земельні, інтелектуальні, промислові, зокрема стабілізовану за кількісними параметрами харчову промисловість) для подолання цієї негативної тенденційності.

Водночас, посилення глобалізаційних та євроінтеграційних процесів в Україні, по-перше, призвели до підвищення чутливості економіки нашої держави до ендо- і екзогенних «шоків», більшої вразливості від зовнішніх загроз i, по-друге, сформували своєрідні інституційні вимоги до форсуючого зростання конкурентоспроможності продовольства, побудови інституційних підвалин імплементації галуззю кращих практик досягнення заздалегідь заданих якісних індикаторів виробництва. Відповідність світовим якісним стандартам може бути досягнута тільки за умови переходу галузі на інноваційну модель розвитку 3 оріснтованістю операційних стратегій підприємств на активне впровадження як процесових, так i технологічних інновацій. Відтак питання щодо підвищення рівня інноватизації вітчизняної харчової галузі, відповідної низки харчових підприємств, виявлення загроз і потенційних можливостей зростання галузі, а також покращення рівня якості та конкурентоспроможності вітчизняних продуктів харчування набувають неабиякої актуальності.

Аналіз останніх публікацій по проблемі. Питанням методологічного, методичного, інструктивного, довідково-статистичного забезпечення процесу переходу харчової промисловості на інноваційноорієнтовану модель розвитку, відповідних державнорегуляторних і інституційних механізмів, присвяченні наукові роботи значної кількості вітчизняних та зарубіжних вчених-економістів, особливе місце серед яких посідають наукові доробки Л. В. Дейнеко, А. О. Заїнчковського, С. М. Ілляшенко, Д. Ф. Крисанова, Ю. Г. Левченко, Т. Л. Мостенської, П. В. Осіпова, С. В. Петруха, О. М. Пєтухової, В. В Россохи, М. П. Сичевського, І. В. Федулової, О. В. Шубравської, П. Друкера (P. Drucker), А. Кляйнкнехта (A. Kleinknecht), M. Портера (M. Porter), Р. Уотермана (R. Waterman), К. Фрімена (C. Freeman), Р. Фостера (C. Foster), Ф. Хаберленда (F. Haberland), Й. Шумпетера (J. Schumpeter) тощо.

Високо оцінуючи їх науковий вклад, варто зазначити, що незважаючи на існування ряду теоретичних та методологічних досліджень в галузі державного регулювання інноваційного розвитку інститу- 
ційних осередків харчової галузі в системному і комплексному вигляді, необхідному для прийняття відповідних управлінських рішень, питання спрямування інноваційного виробництва продуктів харчування до теперішнього часу повністю не вивчено. Практично неопрацьованими залишаються питання підвищення конкурентоспроможності підприємств харчової промисловості - в умовах виконання визначених в рамках національних експертних панелей «Цілей Сталого Розвитку: Україна», зокрема, цілі № 2 «Подолання голоду, розвиток сільського господарства», посилення інтеграції з СОТ і СС, завоювання ними ніші на світовому ринку продовольства. Актуальність переліченої проблематики, науково-практична значущість дослідження разом 3 недостатньо розробленою методологічною базою окремих питань обумовили проведення такого роду досліджень.

Формування цілей дослідження. Метою статті $є$ систематизація і типологізація механізмів державного регулювання інноваційної активності харчової промисловості України, окремих іiі інституційних одиниць в умовах підвищення рівня інтеграції в СОТ та активізації євроінтеграційних процесів.

Виклад основних результатів та їх обгрунтування. Підприємство як складна економічна система являє собою основну ланку соціальноекономічного розвитку держави, іiі конкурентоспроможності у світовому просторі.

Серед усієї сукупності процесів, що відбуваються у підприємницькій діяльності в умовах сьогодення науковці, зокрема [3; 6; 4; 10; 12] виділяють інноваційні як такі, що сприяють розвитку підприємства на якісно новому рівні, за рахунок нововведень.

В науковій економічній літературі $[6,99]$ підкреслюється, що інноваційна політика є частиною загальної політики підприємства. Виступаючи як форма стратегічного управління, вона регламентує взаємодію науково-технічної, маркетингової, виробничої та економічної діяльності в процесі реалізації нововведень, визначає цілі та умови здійснення інноваційної діяльності підприємства, що спрямована на забезпечення його конкурентоспроможності та оптимальне використання наявного виробничого потенціалу.

Звідси обумовленість необхідності розроблення інноваційної політики потребою в стратегічному управлінні інноваційною діяльністю. За умов стрімкого НТП своєчасне та оперативне впровадження новацій забезпечує гнучкість, маневреність підприємства, його здатність пристосуватися до мінливого оточення. Тому, інноваційна політика підприємства має передбачати послідовну цілеспрямовану комплексну інноваційну діяльність щодо зміни будьякого з елементів бізнесу.

Як зазначає дослідник економічної стратегії Я. А. Жаліло [2], майбутнє підприємства в умовах сучасних трансформацій залежить, перш за все, від наявності у нього власної стратегії, а також від того, чи зможе підприємство (організація) послідовно реалізувати цю стратегію на практиці за допомогою конкретних заходів. Нестабільність економіки, нестійкість на ринку і зростаюча складність управління призводять до необхідності уважно вивчити і намагатися впровадити різні варіанти стратегічного розвитку своїх фірм.

Для забезпечення постійного оновлення продукції і вдосконалення виробничих процесів на підприємстві слід постійно виявляти поточні та майбутні проблеми, пов'язані зі зміною життєвого циклу продукції й технології. Це означає здійснення пошукової інноваційної діяльності в різних напрямах з виділенням окремих інноваційних проектів, пріоритетних на час їх актуалізації. Успішне здійснення інноваційної діяльності на підприємстві забезпечує ефективне його функціонування. Згідно Закону України [5], який є базовим регуляторним нормативним документом у даній сфері, «інноваційна діяльність - діяльність, що спрямована на використання і комерціалізацію результатів наукових досліджень та розробок і зумовлює випуск на ринок нових конкурентоздатних товарів і послуг».

Управління сукупністю інноваційних процесів визначає інноваційну політику підприємства, яка формується на основі певних принципів і встановлює зв'язок між розвитком підприємства і напрямами його інноваційної діяльності.

Інноваційна діяльність підприємств в Україні характеризується, як така, що не відповідає сучасному рівню розвитку інноваційних процесів в країнах, для яких інноваційний розвиток є ключовим вектором економічної стратегії [8]. Про низьку інноваційну активність підприємств свідчать показники обсягів реалізованої інноваційної продукції в Україні. Згідно даних державної статистики [11], у загальному обсязі промислової продукції у 2015 році лише 1,4 \% мають ознаки інновацій, з тенденційністю до суттєвого погіршення цього результату (наприклад частка інноваційної продукції у 2000 р. сягала майже $10 \%$ рівня, що більш ніж в 7 разів перевищує показники 2015 року).

В умовах ринкової економіки, однією 3 найважливіших складових національної економіки будьякої країни, є інтелектуалізація промисловості, формування контурів знаннєвої економіки в підприємствах харчової промисловості, оскільки, за експертними оцінками, кожна 4 грн у загальному обсязі реалізованої промислової продукції в Україні - це продукція харчової промисловості. Тобто, харчова галузь є системоутворюючою та однією $з$ найбільш динамічних галузей промисловості України.

Висока соціально-економічна значущість продукції харчових підприємств та наявність великої кількості проблем в забезпеченні їі конкурентоспроможності на внутрішньому та зовнішньому ринках обумовлюють необхідність державного регулювання та стимулювання розвитку інноваційної діяльності підприємств харчової промисловості.

У зв'язку із підписанням та ратифікацією Угоди про асоціацію Україна - СС, перед Україною одночасно відкриваються розширені можливості виходу вітчизняної продукції на зовнішні ринки Свросоюзу (зокрема з 01 жовтня 2017 року набули чинності додаткові автономні торговельні преференції СС 
для України) та постає виклик щодо інтеграції агрохарчового сектору України в єдиний нормативний простір Європейського Союзу. В своїх наукових працях Д. Ф. Крисанов досліджує практичні аспекти подолання викликів і комплексу проблем, які пов’язані iз забезпеченням випуску продукції, яка повністю відповідатиме вимогам європейських та міжнародних стандартів щодо безпечності та якості Він зазначає [7], що саме розроблення та впровадження інноваційної політики підприємствами харчової промисловості може слугувати одним із напрямів вирішення цих проблем на основі переходу від економічної до інноваційної моделі розвитку національної економіки.

А. О. Заїнчковський та М. П. Сичевський [4] визначають, що підвищення конкурентоспроможності продукції, тобто досягнення відповідної якості за вимогами світових стандартів при відносно низькій ціні, можливе лише через впровадження сучасного, новітнього обладнання, ефективних методів організації праці та інноваційно-інвестиційного розвитку виробництва. А це в свою чергу потребує державної підтримки через прийняття відповідних законодавчих i нормативних документів, якими повинно бути передбачено стимулювання інноваційних процесів створення сприятливих умов для вітчизняних та іноземних інвестицій.
Створення сприятливого інноваційного клімату в країні - головне завдання держави на шляху прямування до інноваційної економіки.

Згідно нещодавно опублікованих досліджень інноваційного клімату країн, які проводяться з 2007 року школою бізнесу INSEAD, Світовою організацією інтелектуальної власності спільно з Корнельським університетом, Україна в 2017 році посіла найкращу для себе позицію, а саме 50 місце в рейтингу інноваційних країн світу, який формується на основі показників Глобального інноваційного індексу (GII).

Глобальний інноваційний індекс складається 3 показників розвитку інститутів, людського капіталу і досліджень, інфраструктури, досвіду ринку, бізнесу, знань і технологій, а також творчої діяльності. Оскільки, перелічені вище показники становлять основу інноваційного потенціалу країни, а інновації вважаються найважливішим стимулом економічного зростання і процвітання країни то GII виступає основною оцінкою рівня інноваційного розвитку національної економіки країни.

Зростання позиції в даному рейтингу є надзвичайно позитивною тенденцією для України. Якщо подивитися на динаміку України в рейтингах за останні роки, аналізуючи окремо за критеріями індексу, то отримаємо такий результат (табл.1).

Таблиця 1

Динаміка значень критеріального вимірника Глобального інноваційного індексу України*

\begin{tabular}{|c|c|c|c|c|c|c|c|c|c|c|c|}
\hline \multirow{4}{*}{$\begin{array}{c}\text { Назва критерію } \\
\text { Глобального } \\
\text { інноваційного } \\
\text { індексу }\end{array}$} & \multicolumn{10}{|c|}{ Досліджуванні роки } & \multirow{4}{*}{$\begin{array}{l}\text { Тенден- } \\
\text { ційність }\end{array}$} \\
\hline & \multicolumn{2}{|c|}{2013} & \multicolumn{2}{|c|}{2014} & \multicolumn{2}{|c|}{2015} & \multicolumn{2}{|c|}{2016} & \multicolumn{2}{|c|}{2017} & \\
\hline & бал & місце & бал & місце & бал & місце & бал & місце & бал & місце & \\
\hline & $0-100$ & $1-142$ & $0-100$ & $1-143$ & $0-100$ & $1-141$ & $0-100$ & $1-128$ & $0-100$ & $1-127$ & \\
\hline Інститути & 51,4 & 105 & 52,9 & 103 & 52,2 & 98 & 48,7 & 101 & 47,9 & 101 & $\Rightarrow$ \\
\hline $\begin{array}{l}\text { Людський } \\
\text { капітал i дослі- } \\
\text { дження }\end{array}$ & 37,9 & 44 & 36,6 & 45 & 40,4 & 36 & 40,8 & 40 & 39,6 & 41 & \\
\hline Інфраструктура & 26 & 91 & 27,1 & 107 & 26,3 & 112 & 32,3 & 99 & 39,3 & 90 & \\
\hline Ринковий досвід & 44 & 82 & 45,1 & 90 & 43,9 & 89 & 42,1 & 75 & 43,2 & 81 & \\
\hline $\begin{array}{l}\text { Бізнесовий } \\
\text { досвід }\end{array}$ & 30,2 & 79 & 29,1 & 87 & 32,4 & 78 & 30,6 & 73 & 35,3 & 51 & \\
\hline $\begin{array}{l}\text { Отриманні } \\
\text { знання } \\
\text { та технології } \\
\end{array}$ & 32 & 45 & 38,2 & 32 & 36,4 & 34 & 34,1 & 33 & 32,8 & 32 & \\
\hline $\begin{array}{l}\text { Результати тво- } \\
\text { рчої діяльності }\end{array}$ & 35,3 & 81 & 30,6 & 77 & 31,3 & 75 & 31 & 58 & 36,6 & 49 & \\
\hline $\begin{array}{l}\text { Глобальний } \\
\text { інноваційний } \\
\text { індекс }\end{array}$ & 35,8 & 71 & 36,3 & 63 & 36,5 & 64 & 35,7 & 56 & 37,6 & 50 & \\
\hline
\end{tabular}

*складено автором на основі джерел [14]

**Умовні позначення:

статична поведінка вимірника;
- тенденція відповідно до зменшення чи підвищення вимірника; 
В 2017 році Швейцарія уже сьомий рік підряд займає перше місце загального рейтингу, в якому 24 перші позиції займають країни з високим рівнем доходу. Виключенням являється Китай, який розмістився на 22 місці загального рейтингу та займає лідерську позицію серед рейтингу країн із рівнем доходу вище середнього. Необхідно зазначити, що Україна відноситься до групи країн 3 рівнем доходу нижче середнього та входить до трійки лідерів рейтингу даної групи, займає другу позицію рейтингу, поступившись В'єтнаму.

Проаналізувавши інноваційний індекс України у динаміці останніх років, спостерігаємо позитивну тенденцію зростання рейтингу - 371 місця у 2013 році Україна прогресує та опиняється у 2017 році на рекордному 50 місці, покращивши свій результат на 21 позицію. Інноваційний рейтинг країни у 2017 році оцінений у 37,6 балів, що є показником величезного потенціалу, беручи до уваги те, що у даний час Україна потерпає від військової, інформаційної, економічної та політичної агресії.

Сильними сторонами України залишається розвиток знань та технологій (32 місце), якість людського капіталу (41 місце), результати творчої діяльності (49 місце), які значно покращуються в останньому році, та розвиток бізнесу (51 місце).

Слабкими сторонами України $є$ розвиток ринкових відносин (81 місце), інфраструктура (90 місце, проте значно краще минулорічного 99 місця), а найбільш вразливим сектором залишається недосконале інституційне середовище (101 місце).

Тобто, абсолютно зрозуміло, що без докорінних змін у системі освіти, без нових правил і норм у суспільстві, без реформування держави в сфері забезпечення створення конкурентної продукції та виходу на нові ринки Україні реалізувати свій інноваційний потенціал та досягти бажаного результату буде вкрай важко.

В основі головної теми дослідження інноваційного клімату країн 2017 року «Інновації годують світ» є аналіз стану інноваційної діяльності в рамках агропродовольчої системи. Автори говорять про те, що в наступні десять років агропромисловий сектор зустрінеться із колосальним зростанням світового попиту, яке характеризується прогнозованим зростанням населення до 9,7 мільярдів людей та загостреною конкурентною боротьбою за обмежені природні ресурси. Перед виробниками харчової продукції гостро постане проблема адаптації до зміни клімату та пом'якшення процесу таких змін. I саме Інновації виступають ключовим інструментом підтримки розвитку виробництва, необхідного для задоволення зростаючого глобального попиту.

Виконавчий директор Відділення глобальних індексів школи бізнесу INSEAD Бруно Ланвен [15] говорить: «На наших очах у всьому світі вже народжується «цифрове сільське господарство» 3 безпілотними літальними апаратами, супутниковими датчиками і польовою робототехнікою. Зараз гостро відчувається необхідність «розумного сільського господарства» для оптимізації виробничо-збутових і розподільчих систем і стимулювання впровадження тво- рчих нових бізнес-моделей, які зводять до мінімуму навантаження на земельні, енергетичні та інші природні ресурси, в той же час дозволяючи приділяти увагу потребам найбіднішого населення світу».

Для України питання забезпечення харчовими продуктами бідніших верств населення є надзвичайно актуальним. Оскільки, згідно стратегії подолання бідності [13], рівень бідності в країні залишається стабільно високим. За даними дев'яти місяців 2015 року, за межею відносної бідності за витратами перебувало 23,8 відсотка населення.

Неприпустимо високою є частка витрат населення на харчування. У 2015 році ця частка становить 54,6 \% загальних сукупних витрат, що у 3-5 разів перевищує витрати населення країн Європейського Союзу. У домогосподарствах із найнижчим рівнем доходу частка витрат на харчування становила 63\% при граничному національному критерії встановленому для цього показника на рівні $60 \%$.

Тобто населення країни більше половини своїх доходів витрачає на харчування. А це, як зазначено в працях Т. Л. Мостенської [10], несе потенційну загрозу продовольчій безпеці, створюючи проблему фізичного, соціального та економічного доступу для всіх верст населення до раціональних норм споживання, які грунтуються на потребах людей в енергії, білках і поживних речовинах для того, щоб вони могли жити, вести будь-яку діяльність протягом тривалого періоду часу.

Оптимальною вважається ситуація, коли фактичне споживання продуктів харчування однією людиною впродовж року відповідає встановленій раціональній нормі. Проведено аналіз відповідності фактичного споживання окремих видів продукції в кілограмах на душу населення України, згідно даних Державної служби статистики України [11], рекомендованим нормам, затвердженим Міністерством охорони здоров'я України в «Орієнтовному наборі основної продовольчої сировини і харчових продуктів для забезпечення у середньому на душу населення на 2005-2015 роки», для визначення контурів прихованого голоду (рис.1).

У 2016 році в Україні по досліджуваних групах продовольства фактичне споживання знаходилося значно нижче рівня раціональних норм. Помітне відставання фактичного споживання м'ясо-молочної та ягідно-фруктової продукції від раціональних норм.

Спостерігається відсутність збалансованого харчування. Споживання жителем країни м'яса i м'ясопродуктів становить $64 \%$ науково обгрунтованої норми, молока і молокопродуктів - 55\%. Споживання фруктів, ягід, горіхів, які є основним джерелом вітамінів для організму людини, також суттєво - на $43 \%$ - відстає від нормативного показника.

Як і в попередні роки, фактичне споживання за продовольчою групою «хліб і хлібопродукти» відповідає або в деяких регіонах перевищує раціональну норму, що є свідченням розбалансованості харчування населення, яке намагається забезпечити власні енергетичні потреби за рахунок більш економічно доступних продуктів. 


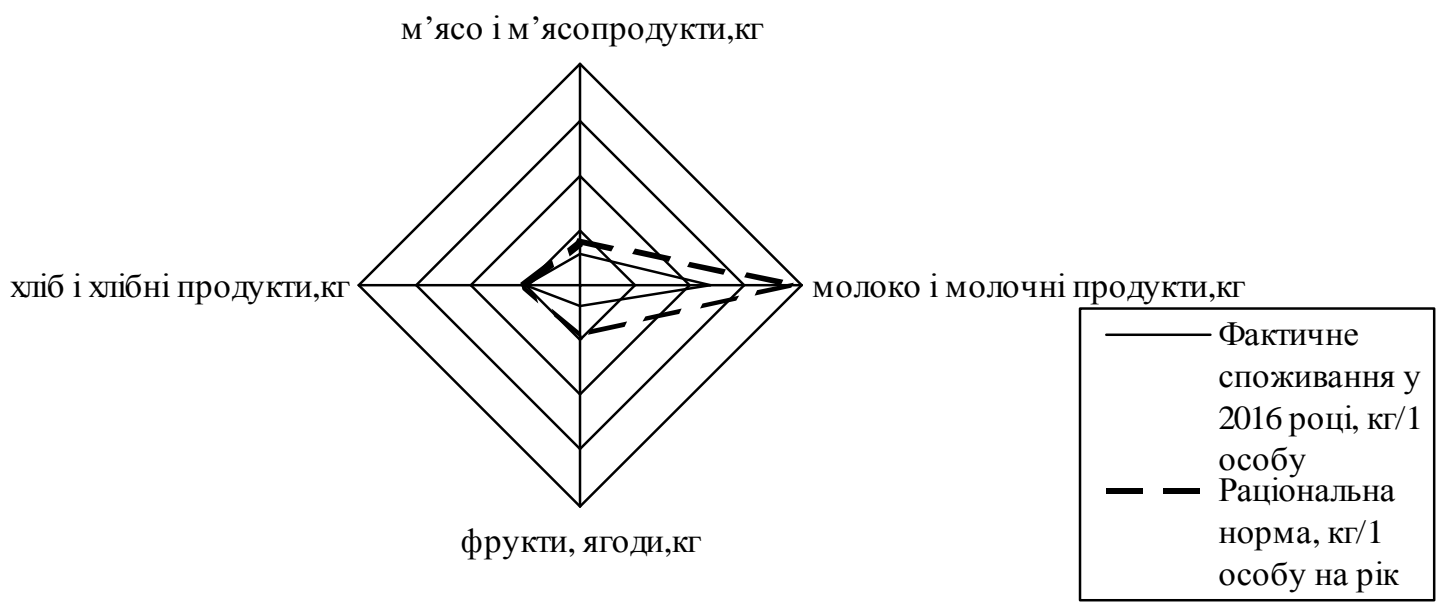

\section{Рис. 1. Співвідношення фактичного та раціональної норми споживання основних продуктів харчування в Україні* \\ * розроблено автором на основі джерел [11]}

Відповідно до Цілей сталого розвитку (20152030 роки) [9], схвалених на Саміті ООН у вересні 2015 року, забезпечення доступності збалансованого харчування для населення України, насамперед для найбідніших верств ії населення, має стати пріоритетом державної політики на найближчі 15 років. I до 2030 року споживання населенням України основних видів продовольства (м'яса, молока, фруктів), яке $\epsilon$ недостатнім, має бути доведеним до науково обгрунтованого рівня.

Автор вважає, що саме ефективне стимулювання та економічна підтримка інноваційної діяльності харчової промисловості надасть значний поштовх для розвитку підприємств даної галузі та забезпечить перехід від кількісних до якісних показників харчової продукції. Забезпечення конкурентоспроможної продукції стане приводом для збільшення присутності харчових продуктів на зовнішніх ринках, суттєво покращивши структуру експорту продукції.

Гарантування продовольчої безпеки України $є$ проблемою, актуальність якої щороку наростає. Л. В. Дейнеко [1] підкреслює, що диспропорція та нерентабельність виробництва сільськогосподарської продукції, високий рівень імпорту продуктів харчування, значний рівень зношуваності основних засобів на підприємствах, не сформованість ринкової інфраструктури зумовлюють необхідність розвитку інноваційних виробництв харчових продуктів, здійснюючи структурну оптимізацію та підвищуючи його ефективність.
Розвиток національної економіки сприятиме підвищенню рівня доходів населення та забезпеченню продовольчої безпеки країни, тобто створюватиме умови для доступу населення до збалансованого та раціонального споживання харчових продукті.

Висновки та перспективи подальшого дослідження. Інноваційна діяльність в Україні знаходиться в незадовільному стані та характеризується низьким рівнем активності, чого не можна сказати про низку «нових» галузей харчової промисловості, серед яких особливе місце займають олійно-жирова, борошномельна, пивоварна, тютюнова. Водночас низка «старих» галузей (цукрова, хлібопекарська, спиртова, молочна, м'ясна) знаходяться або на трансформаційному етапі свого розвитку («нове життя»), або етапі «затухання». Керуючись визначеною «ентропією» споживання ключових видів продовольства, автор вважає, що подальший розвиток регуляторних механізмів активізації інноваційної діяльності повинен бути акцентований на таких галузях харчової промисловості, як м'ясо-молочна та виробництво фруктів і овочів. Це дозволить збалансувати раціон харчування українців, забезпечити реалізацію Цілей сталого розвитку до 2030 року, а також сталий розвиток визначених інституційних осередків харчової промисловості. Подолання контурів прихованого голоду, збільшення доходів населення та подолання високого показника бідності є стратегічним напрямком для України в майбутньому.

\section{Література}

1. Дейнеко Л. В. Комплексне дослідження інноваційного розвитку сфери виробництва продуктів харчування в умовах посилення ризиків продовольчої безпеки [Електронний ресурс] / Л. В. Дейнеко // Регіональна економіка. - 2013. - № 2. - С. 219-221. - Режим доступу: http://nbuv.gov.ua/UJRN/regek_2013_2_27.

2. Жаліло Я. А. Економічна стратегія як категорія сучасної економічної науки / Я. А. Жаліло // Економіка України. - 2005. - № 1. - С. 19-27. 
3. Жужукіна Н. І. Парадигма регіонального інноваційного розвитку хлібопекарських підприємств України / Н. І. Жужукіна, С. В. Петруха, М. М. Колотуша // Економіст. - 2008. - № 4. - С. 28-43.

4. Заїнчковський А. О. Стан і перспективи розвитку підприємств харчової та переробної промисловості України / А. О. Заїнчковський, М. П. Сичевський // Вісник соціально-економічних досліджень. - 2011. - № 2. C. 22-26.

5. Закон України «Про інноваційну діяльність» від 04.07.2002 р. № 40-IV: за станом на 01 жовтня 2017 p. - [Електронний ресурс]. - Режим доступу : http://zakon3.rada.gov.ua.

6. Йохна М. А. Економіка і організація інноваційної діяльності. / М. А. Йохна, В. В. Стадник. - К. : Видавничий центр «Академія», 2005. - 400 с.

7. Крисанов Д. Ф. Стратегія нарощування інноваційного потенціалу підприємствами харчової промисловості / Д. Ф. Крисанов, Л. Д Водянка // Економіка і прогнозування. - 2015. - № 1. - С. 89-104.

8. Левченко Ю. Г. Активізація інноваційної діяльності вітчизняних підприємств в умовах кризи [Електронний ресурс] / Ю. Г. Левченко // Всеукраїнська наук.-прак. on-line конф. аспірантів, молодих учених та студентів, присвячена Дню науки : тези доповіді // Електронний архів Житомирського державного технологічного університету. - 2017. - Режим доступу: http://eztuir.ztu.edu.ua/123456789/6813.

9. Міністерство економічного розвитку і торгівлі «Цілі Сталого Розвитку: Україна. Національна доповідь 2017». - [Електронний ресурс]. - Режим доступу: http://www.me.gov.ua.

10. Мостенська Т. Л. Харчування як складова продовольчої безпеки [Електронний ресурс] / Т. Л. Мостенська, Г. О. Кундєєва // Наукові праці Національного університету харчових технологій. - 2016. - Том 22, № 3. - С. 113-122. - Режим доступу: http://dspace.nuft.edu.ua/jspui/handle/123456789/23714.

11. Офіційний веб-сайт сайт Державної служби статистики України. - [Електронний ресурс]. - Режим доступу: http://www.ukrstat.gov.ua.

12. Петруха С. В. Методологія комплексного аналізу інноваційної активності вітчизняної харчової індустрії / С. В. Петруха, М. М. Колотуша // Економіст. - 2007. - № 4. - С. 50-56.

13. Розпорядження Кабінету Міністрів України «Про схвалення стратегії подолання бідності» від 16.03.2016 p. №161-p. [Електронний ресурс]. - Режим доступу: http://zakon3.rada.gov.ua.

14. Official web-site of the WIPO. World Intellectual Property Organization. - [Electronic resource]. - Mode of access: http://www.wipo.int/publications/en/details.jsp?id=4193

15. Global Innovation Index 2017 / ed.S. Dutta, INSEAD. - The Business School of The World, 2017. - 303 p.

Стаття надійшла 21.10.2017

Стаття прийнята до друку 31.10.2017

Доступно в мережі Internet 30.12.2017

\author{
Хрипьюк В. И. \\ аспирант \\ кафедра экономики и права \\ Национальный университет пищевых технологий \\ ул. Владимирская, 68, г. Киев, Украина, 01601 \\ E-mail: viktorija2511@ukr.net
}

\title{
ГОСУДАРСТВЕННОЕ РЕГУЛИРОВАНИЕ ИННОВАЦИОННО- ОРИЕНТИРОВАННОГО РАЗВИТИЯ ПРОМЫШЛЕННОСТИ УКРАИНЫ
}

В статье рассмотрены теоретические основы композиции государственного регуляторного механизма активизации инновационных процессов в определенных институциональных звеньях пищевой промышленности Украины. Определены «сильные» и «слабые» регуляторные рычаги (через критериальный базис общепризнанного Глобального инновационного индекса, который состоит из показателей развития институтов, человеческого капитала и исследований, инфраструктуры, уровень развития рынка, уровень развития бизнеса, знаний и технологий, а также творческой деятельности), формирующие инновационный климат в агропродовольственном секторе страны.

Исследовано что инновационные деятельность предприятий в Украине характеризуется, как таковая, что не соответствует современному уровню развития инновационных процессов в странах, для которых инновационное развитие является ключевым вектором экономической стратегии. Наличие большого количества проблем в обеспечение конкурентоспособности пищевой продукции на внутреннем и внешнем рынках, так как подписано и ратифицировано Соглашения об ассоциации Украина - EC, обусловливают необходимость государственного регулирования и стимулирования развития инновационной деятельности предприятий пищевой промышленности. Обеспечение 
конкурентоспособной продукции станет поводом для увеличения присутствия пищевых продуктов на внешних рынках, существенно улучшив структуру экспорта продукции.

Обоснованы перспективные направления совершенствования государственного регулирования инновационного развития пищевой промышленности Украины и с использованием авторского подхода определены соответствующие отраслевые приоритеты.

Сделаны выводы, что инновационно-ориентированное развитие пищевой промышленности позволит сбалансировать рацион питания украинцев, и обеспечить реализацию Целей устойчивого развития до 2030 года (2015-2030 годы), принятых на Саммите ООН в сентябре 2015 года. Так как, преодоление контуров скрытого голода, увеличение доходов населения и преодоления высокого показателя бедности является стратегическим направлением для Украины в будущем.

Ключевые слова: государственное регулирование, инновационная активность, глобальный инновационный индекс, пищевая промышленность, продовольственная безопасность.

\author{
Khrypiuk V. \\ Postgraduate \\ Department of Economics and Law \\ National University of Food Technologies \\ Volodymyrska str., 68, 01601 Kyiv, Ukraine \\ E-mail: viktorija2511@ukr.net
}

\title{
STATE REGULATION OF INNOVATION-ORIENTED DEVELOPMENT OF THE FOOD INDUSTRY OF UKRAINE
}

The article deals with the theoretical bases of the composition of the state regulatory mechanism of activation of innovative processes in certain institutional links of the food industry of Ukraine. The strong and weak regulatory levers which form an innovative climate in the agro-food sector of the country have been defined (through the criterial basis of the world recognized Global Innovation Index, which consists of the indicators of institutions development, human capital and research, infrastructure, market development level, business development level, knowledge and technology level, and creative activities).

It has been investigated that the innovative activity of enterprises in Ukraine is characterized as such, and it does not correspond to the current level of development of innovative processes in the countries for which innovative development is the key vector of economic strategy. The presence of a large number of problems in ensuring the competitiveness of food products in the domestic and foreign markets, as the Agreement on the Ukraine-EU Association signed and ratified, necessitate the government regulation and stimulation of the development of innovative activities of food industry enterprises. Provision of competitive products will be an incentive for increasing the presence of food products in foreign markets, significantly improving the structure of exports of products.

Prospective directions of perfection of state regulation of innovative development of the food industry of Ukraine has been grounded and the corresponding branch priorities has been identified using the author's approach.

It has been concluded that innovation-oriented development of the food industry will help to balance the nutrition of Ukrainians and ensure implementation of the Sustainable Development Goals by 2030 (20152030), approved at the UN Summit in September 2015. So, overcoming of the contours of latent hunger, increasing of population incomes and overcoming the of high poverty rate is a strategic direction for Ukraine in the future.

Keywords: state regulation, innovative activity, innovations, Global Innovation Index, Food Industry, food safety.

\section{References}

1. Deineko, L. V. (2013). Kompleksne doslidzhennia innovatsiinoho rozvytku sfery vyrobnytstva produktiv kharchuvannia v umovakh posylennia ryzykiv prodovolchoi bezpeky. Rehionalna ekonomika, (2), 219-221. Retrieved from http://nbuv.gov.ua/UJRN/regek 2013_2_27

2. Zhalilo, Ia. A. (2005). Ekonomichna stratehiia yak katehoriia suchasnoi ekonomichnoi nauky. Ekonomika Ukrainy, (1), 19-27.

3. Zhuzhukina, N. I., Petrukha, S. V., \& Kolotusha, M. M. (2008). Paradyhma rehionalnoho innovatsiinoho rozvytku khlibopekarskykh pidpryiemstv Ukrainy. Ekonomist, (4), 28-43. 
4. Zainchkovskyi, A. O., \& Sychevskyi, M. P. (2011). Stan i perspektyvy rozvytku pidpryiemstv kharchovoi ta pererobnoi promyslovosti Ukrainy. Visnyk sotsialno-ekonomichnykh doslidzhen,(2), 22-26.

5. Zakon Ukrainy «Pro innovatsiinu diialnist» vid 04.07.2002 r. № 40-IV: za stanom na 01 zhovtnia 2017 r. (2012). Retrieved from http://zakon3.rada.gov.ua.

6. Yokhna, M. A., \& Stadnyk, V. V. (2005). Ekonomika i orhanizatsiia innovatsiinoi diialnosti. K.: Vydavnychyi tsentr «Akademiia».

7. Krysanov, D. F., \& Vodianka, L. D. (2015). Stratehiia naroshchuvannia innovatsiinoho potentsialu pidpryiemstvamy kharchovoi promyslovosti. Ekonomika i prohnozuvannia, (1), 89-104.

8. Levchenko, Iu. H. (2017, May 17). Aktyvizatsiia innovatsiinoi diialnosti vitchyznianykh pidpryiemstv v umovakh kryzy. Retrieved June 09, 2017, from http://eztuir.ztu.edu.ua/123456789/6813

9. Ministerstvo ekonomichnoho rozvytku i torhivli «Tsili Staloho Rozvytku: Ukraina. Natsionalna dopovid 2017». (2017). Retrieved from http://www.me.gov.ua.

10. Mostenska, T. L., \& Kundieieva, H. O. (2016). Kharchuvannia yak skladova prodovolchoi bezpeky. Naukovi pratsi Natsionalnoho universytetu kharchovykh tekhnolohii, 22(3), 113-122. Retrieved from http://dspace.nuft.edu.ua/jspui/handle/123456789/23714

11. Ofitsiinyi veb-sait sait Derzhavnoi sluzhby statystyky Ukrainy. (2017). Retrieved from http://www.ukrstat.gov.ua.

12. Petrukha, S. V., \& Kolotusha, M. M. (2007). Metodolohiia kompleksnoho analizu innovatsiinoi aktyvnosti vitchyznianoi kharchovoi industrii. Ekonomist, (4), 50-56.

13. Rozporiadzhennia Kabinetu Ministriv Ukrainy «Pro skhvalennia stratehii podolannia bidnosti» vid 16.03.2016 r. №161-r. (2016). Retrieved from http://zakon3.rada.gov.ua.

14. Official web-site of the WIPO. World Intellectual Property Organization. (2017). Retrieved from http://www.wipo.int/publications/en/details.jsp?id=4193

15. Dutta, S. (Ed.). (2017). Global Innovation Index 2017 . INSEAD. - The Business School of The World.

Received 21 October 2017

Approved 31 October 2017

Available in Internet 30.12.2017 